\title{
Optical Properties of Opal Glass on the Various Contents of Chemical Composition
}

\author{
Tuan Dung Nguyen*, Bramhe Sachin N.*, Ji Ho Kim* and Taik-Nam Kim***† \\ *Department of Materials Science and Engineering, Graduate School of PaiChai University, Daejeon 302-735, Korea \\ **Department of Information and Electronic Materials Engineering, PaiChai University, Daejeon 302-735, Korea
}

(Received October 18, 2012 : Received in revised form December 4, 2012 : Accepted December 6, 2012)

\begin{abstract}
Opal glass samples having different chemical compositions were synthesized and transparent glass was obtained after melting. The effects of $\mathrm{TiO}_{2}, \mathrm{BaF}_{2}$, and $\mathrm{CeO}_{2}$ content on the color of the opal glass were studied by observing images of the opal samples and analyzing the results via ultraviolet visible spectroscopy and color spectrometry. The aesthetic properties of the opal glass were determined by studying the transmittance of visible light in the $400 \mathrm{~nm}$ to $700 \mathrm{~nm}$ range. The basic chemical composition of opal glass was $\mathrm{SiO}_{2} 52.9 \mathrm{wt} \%, \mathrm{Al}_{2} \mathrm{O}_{3} \quad 12.35 \mathrm{wt} \%, \mathrm{Na}_{2} \mathrm{CO}_{3} 15.08 \mathrm{wt} \%, \mathrm{~K}_{2} \mathrm{CO}_{3} \quad 10.35 \mathrm{wt} \%, \mathrm{Ca}_{3}(\mathrm{PO})_{4}$ $4.41 \mathrm{wt} \%, \mathrm{MgCO}_{3} 1.844 \mathrm{wt} \%, \mathrm{LiCO}_{3} 2.184 \mathrm{wt} \%$, and $\mathrm{TiO}_{2} 0.882 \mathrm{wt} \%$. The glass samples were prepared by varying the weight percentage of $\mathrm{TiO}_{2}, \mathrm{BaF}_{2}$, and $\mathrm{CeO}_{2}$. The transmittance of visible light was decreased from $95 \%$ to $75 \%$ in the glass samples in which $\mathrm{TiO}_{2}$ content was increased from 0 to $3.882 \mathrm{wt} \%$. In the blue spectrum region, as the content of $\mathrm{TiO}_{2}$ increased, the reflectance value was observed to become higher. This implies that $\mathrm{TiO}_{2}$ content induces more crystal formation and has an important effect on the optical properties of the glass. The opalescence of opal samples that contained $\mathrm{CeO}_{2}$ or $\mathrm{BaF}_{2}$ is stronger than that in the samples containing $\mathrm{TiO}_{2}$. Opal glass samples comprising $\mathrm{TiO}_{2}$ had tetragonal lattice structures; samples including $\mathrm{CeO}_{2}$ as an additive had cubic lattice structures $\left(\mathrm{FCC}, \mathrm{CeO}_{2}\right)$.
\end{abstract}

Key words opal glass, $\mathrm{TiO}_{2}, \mathrm{BaF}_{2}, \mathrm{CeO}_{2}$, optical properties.

\section{Introduction}

Recently, the development and synthesis of Opal glass has attracted a great deal of attention because of its optical properties. ${ }^{1-3)}$ Opal glasses are desirable for consumer product applications, such as tableware and are widely used in dental application and jewel fields. The artificial Opal mainly contains silicate nano sized spheres ordered in a hexagonal or cubic close-packed lattice. The interference and diffraction of light passing through the microstructure of the Opal produces the internal colors. ${ }^{4)}$ The propagation of electromagnetic waves of certain energy is thus forbidden due to the strong diffraction of light by the sphere planes(partial or total suppression of the photon density of states). ${ }^{5,6)}$ This property leads to their application in a wide range of products, such as novel chemical and biological sensors or low threshold laser design, etc. ${ }^{6}$ It has already been shown that optical properties of opal glass are influenced by their structural parameters, chemical composition, the defect density and the refractive index contrast inside the photonic crystal. ${ }^{1,7,8)}$

Some investigators have shown the effect of composition and heat treatment on the microstructure, and the optical properties of opal glasses. ${ }^{2,9,10)}$ It has also been shown that the addition of $\mathrm{RO}$ oxides $(\mathrm{R}=\mathrm{Ti}, \mathrm{Ca}, \mathrm{Na}, \mathrm{Al}$, $\mathrm{Ba}, . .$.$) to silicate glasses, though is essential for enhanced$ opacity, may generally be detrimental for chemical durability. ${ }^{11)}$

In this paper, a systematic effort is made to show and compare the effect of Titanium Dioxide $\left(\mathrm{TiO}_{2}\right)$, Barium Fluoride $\left(\mathrm{BaF}_{2}\right)$, and Cerium Dioxide $\left(\mathrm{CeO}_{2}\right)$ additions on optical properties of Opal glass. Titanium oxide or Cerium oxide has been commonly recognized as the most important candidates of opal glasses due to its high chemical stability, with wide applications in photovoltaic cell, photocatalysis, and catalytic supports. ${ }^{4)}$ The important role of $\mathrm{TiO}_{2}, \mathrm{BaF}_{2}$ and $\mathrm{CeO}_{2}$ are well known for the nucleation and crystalline growth, ${ }^{12,13)}$ which induce more crystal

\footnotetext{
${ }^{\dagger}$ Corresponding author

E-Mail : tnkim@pcu.ac.kr (T. -N. Kim, Paichai Univ.)
}

(C) Materials Research Society of Korea, All rights reserved.

This is an Open-Access article distributed under the terms of the Creative Commons Attribution Non-Commercial License (http://creativecommons.org/licenses/by-nc/3.0) which permits unrestricted non-commercial use, distribution, and reproduction in any medium, provided theoriginal work is properly cited. 
formation and is the main reason causes opalescence property of glass. Due to opalescence is caused by the reflection of short wavelength light, which is affected by crystal formation in the glass structure. Therefore, this experiment applied chemical additives such as $\mathrm{TiO}_{2}, \mathrm{BaF}_{2}$ and $\mathrm{CeO}_{2}$ to investigate the optical properties of Opal glass.

\section{Experimental Procedure}

In the present investigation, the main purpose is synthesis of opal glass and studying the effect of chemical compositions such as $\mathrm{TiO}_{2}, \mathrm{BaF}_{2}$ and $\mathrm{CeO}_{2}$ on optical properties of opal glass. The basic chemical composition of opal glass was $\mathrm{SiO}_{2} 52.9 \mathrm{wt} \%, \mathrm{Al}_{2} \mathrm{O}_{3} 12.35 \mathrm{wt} \%$, $\mathrm{Na}_{2} \mathrm{CO}_{3} 15.08 \mathrm{wt} \%, \mathrm{~K}_{2} \mathrm{CO}_{3} 10.35 \mathrm{wt} \%, \mathrm{Ca}_{3}(\mathrm{PO})_{4} 4.41$ $\mathrm{wt} \%, \mathrm{MgCO}_{3} 1.844 \mathrm{wt} \%, \mathrm{LiCO}_{3} 2.184 \mathrm{wt} \%$ and $\mathrm{TiO}_{2}$ $0.882 \mathrm{wt} \%$. The chemicals in the $\mathrm{SiO}_{2}-\mathrm{Al}_{2} \mathrm{O}_{3}-\mathrm{Na}_{2} \mathrm{CO}_{3}$ $\mathrm{K}_{2} \mathrm{CO}_{3}-\mathrm{Ca}_{3}(\mathrm{PO})_{4}-\mathrm{MgCO}_{3}-\mathrm{TiO}_{2}-\mathrm{BaF}_{2}-\mathrm{CeO}_{2}$ system were prepared, varying the weight percentage of $\mathrm{TiO}_{2}, \mathrm{BaF}_{2}$ and $\mathrm{CeO}_{2}$, one at a time, while other additive components kept constant or changed slightly.

The experiment was carried out in three groups to study the effect of each of the three chemicals :

$$
\begin{aligned}
& \text { + Group 1: Effect of Titanium Oxide }\left(\mathrm{TiO}_{2}\right) \\
& \text { + Group 2: Effect of Barium Fluoride }\left(\mathrm{BaF}_{2}\right) \\
& \text { + Group 3: Effect of Cerium Oxide }\left(\mathrm{CeO}_{2}\right)
\end{aligned}
$$

The compositions of samples were listed in following Table 1, Table 2 and Table 3. The opal glass was prepared by the conventional solid state method. The process to prepare opal glass is schematically illustrated in Fig. 1. Each sample had the final mass of 10 gram. The experiment was carried out with 15 samples for 3 groups(5 samples per group). One important thing to pay attention is the weight percentage of $\mathrm{TiO}_{2}, \mathrm{BaF}_{2}$ and $\mathrm{CeO}_{2}$.

The stoichiometric composition of opal glass was first mixed in ethanol for 1 hour using the pestle and the mortar. Then the mixture was dried at $100^{\circ} \mathrm{C}$ in a drying oven(SW-90D Sangwoo scientific company). Next the mixtures were put into a Platinum crucible $(50 \mathrm{cc})$ and carefully placed into the chamber of an electrical furnace(CBFS001).

The mixed powder was then melted at $1500{ }^{\circ} \mathrm{C}$ for around 60 minutes in the electrical furnace(Set up speed of melting : $5^{\circ} \mathrm{C} /$ minute). After the melting process, samples were taken out using the gloves and protective glasses.

\begin{tabular}{|c|c|c|c|c|c|c|c|c|c|c|}
\hline \multirow{2}{*}{$\begin{array}{l}\text { Chemical } \\
\text { composition }\end{array}$} & \multicolumn{2}{|c|}{ Sample 1} & \multicolumn{2}{|c|}{ Sample 2} & \multicolumn{2}{|c|}{ Sample 3} & \multicolumn{2}{|c|}{ Sample 4} & \multicolumn{2}{|c|}{ Sample 5} \\
\hline & $\% \mathrm{wt}$ & $\%$ mole & $\% \mathrm{wt}$ & $\%$ mole & $\%$ wt & $\%$ mole & $\% \mathrm{wt}$ & $\%$ mole & $\%$ wt & $\%$ mole \\
\hline $\mathrm{SiO}_{2}$ & 53.4 & 68.57 & 52.9 & 68.41 & 51.9 & 67.81 & 51.9 & 67.98 & 51.4 & 67.5 \\
\hline $\mathrm{Al}_{2} \mathrm{O}_{3}$ & 12.73 & 9.63 & 12.35 & 9.328 & 12.35 & 9.407 & 12.00 & 9.263 & 11.85 & 9.147 \\
\hline $\mathrm{Na}_{2} \mathrm{CO}_{3}$ & 15.18 & 11.02 & 15.08 & 11.04 & 15.08 & 11.13 & 14.53 & 10.79 & 14.58 & 11.19 \\
\hline $\mathrm{K}_{2} \mathrm{CO}_{3}$ & 10.25 & 5.722 & 10.35 & 5.83 & 10.35 & 5.879 & 10.25 & 5.837 & 10.00 & 5.713 \\
\hline $\mathrm{Ca}_{3}\left(\mathrm{PO}_{4}\right)_{2}$ & 4.41 & 1.095 & 4.41 & 1.105 & 4.41 & 1.114 & 4.41 & 1.119 & 4.26 & 1.083 \\
\hline $\mathrm{MgCO}_{3}$ & 1.844 & 1.691 & 1.844 & 1.706 & 1.844 & 1.721 & 1.844 & 1.721 & 1.844 & 1.731 \\
\hline $\mathrm{Li}_{2} \mathrm{CO}_{3}$ & 2.186 & 2.272 & 2.184 & 2.291 & 2.184 & 2.314 & 2.184 & 2.326 & 2.184 & 2.326 \\
\hline $\mathrm{TiO}_{2}$ & 0 & 0 & 0.882 & 0.29 & 1.882 & 0.625 & 2.882 & 0.959 & 3.882 & 1.297 \\
\hline Sum $\%$ & \multicolumn{2}{|c|}{100} & \multicolumn{2}{|c|}{100} & \multicolumn{2}{|c|}{100} & \multicolumn{2}{|c|}{100} & \multicolumn{2}{|c|}{100} \\
\hline
\end{tabular}
Water quenching was conducted after the melt. The opal

Table 1. Chemical composition of experiment samples of group 1 (weight percent and mole percent).

\begin{tabular}{|c|c|c|c|c|c|c|c|c|c|c|}
\hline \multirow{2}{*}{$\begin{array}{l}\text { Chemical } \\
\text { composition }\end{array}$} & \multicolumn{2}{|c|}{ Sample 6} & \multicolumn{2}{|c|}{ Sample 7} & \multicolumn{2}{|c|}{ Sample 8} & \multicolumn{2}{|c|}{ Sample 9} & \multicolumn{2}{|c|}{ Sample 10} \\
\hline & $\% \mathrm{wt}$ & $\%$ mole & $\% \mathrm{wt}$ & $\%$ mole & $\%$ wt & $\%$ mole & $\%$ wt & $\%$ mole & $\%$ wt & $\%$ mole \\
\hline $\mathrm{SiO}_{2}$ & 61.0 & 69.93 & 60.5 & 69.63 & 60.0 & 69.32 & 59.5 & 68.99 & 59.5 & 69.095 \\
\hline $\mathrm{Al}_{2} \mathrm{O}_{3}$ & 14.5 & 9.774 & 14.5 & 9.808 & 14.5 & 9.843 & 14.5 & 9.88 & 14.0 & 9.552 \\
\hline $\mathrm{B}_{2} \mathrm{O}_{3}$ & 6.0 & 6.073 & 6.0 & 6.094 & 6.0 & 6.116 & 6.0 & 6.142 & 6.0 & 6.151 \\
\hline $\mathrm{Na}_{2} \mathrm{O}$ & 9.0 & 9.98 & 9.0 & 10.01 & 9.0 & 10.05 & 9.0 & 10.09 & 9.0 & 10.109 \\
\hline $\mathrm{K}_{2} \mathrm{O}$ & 4.0 & 2.928 & 4.0 & 2.939 & 4.0 & 2.949 & 4.0 & 2.962 & 4.0 & 2.966 \\
\hline $\mathrm{Ca}_{3}\left(\mathrm{PO}_{4}\right)_{2}$ & 5.0 & 1.11 & 5.0 & 1.114 & 5.0 & 1.118 & 5.0 & 1.123 & 5.0 & 1.124 \\
\hline $\mathrm{CeO}_{2}$ & 0.5 & 0.2 & 0.5 & 0.2 & 0.5 & 0.201 & 0.5 & 0.202 & 0.5 & 0.203 \\
\hline $\mathrm{BaF}_{2}$ & 0 & 0 & 0.5 & 0.197 & 1.0 & 0.396 & 1.5 & 0.596 & 2.0 & 0.797 \\
\hline Sum $\%$ & \multicolumn{2}{|c|}{100} & \multicolumn{2}{|c|}{100} & \multicolumn{2}{|c|}{100} & \multicolumn{2}{|c|}{100} & \multicolumn{2}{|c|}{100} \\
\hline
\end{tabular}

Table 2. Chemical composition of experiment samples of group 2 (weight percent and mole percent). 
Table 3. Chemical composition of experiment samples of group 3 (weight percent and mole percent).

\begin{tabular}{|c|c|c|c|c|c|c|c|c|c|c|}
\hline \multirow{2}{*}{$\begin{array}{l}\text { Chemical } \\
\text { composition }\end{array}$} & \multicolumn{2}{|c|}{ Sample 11} & \multicolumn{2}{|c|}{ Sample 12} & \multicolumn{2}{|c|}{ Sample 13} & \multicolumn{2}{|c|}{ Sample 14} & \multicolumn{2}{|c|}{ Sample 15} \\
\hline & $\% \mathrm{wt}$ & $\%$ mole & $\% \mathrm{wt}$ & $\%$ mole & $\%$ wt & $\%$ mole & $\% \mathrm{wt}$ & $\%$ mole & $\% \mathrm{wt}$ & $\%$ mole \\
\hline $\mathrm{SiO}_{2}$ & 60.5 & 69.63 & 60.25 & 69.47 & 60.0 & 69.32 & 59.75 & 69.14 & 59.75 & 69.242 \\
\hline $\mathrm{Al}_{2} \mathrm{O}_{3}$ & 14.5 & 9.809 & 14.5 & 9.826 & 14.5 & 9.843 & 14.5 & 9.868 & 14.25 & 9.663 \\
\hline $\mathrm{B}_{2} \mathrm{O}_{3}$ & 6.0 & 6.095 & 6.0 & 6.105 & 6.0 & 6.116 & 6.0 & 6.131 & 6.0 & 6.133 \\
\hline $\mathrm{Na}_{2} \mathrm{O}$ & 9.0 & 10.01 & 9.0 & 10.03 & 9.0 & 10.05 & 9.0 & 10.07 & 9.0 & 10.08 \\
\hline $\mathrm{K}_{2} \mathrm{O}$ & 4.0 & 2.939 & 4.0 & 2.944 & 4.0 & 2.949 & 4.0 & 2.957 & 4.0 & 2.958 \\
\hline $\mathrm{Ca}_{3}\left(\mathrm{PO}_{4}\right)_{2}$ & 5.0 & 1.114 & 5.0 & 1.116 & 5.0 & 1.118 & 5.0 & 1.121 & 5.0 & 1.121 \\
\hline $\mathrm{BaF}_{2}$ & 1.0 & 0.395 & 1.0 & 0.395 & 1.0 & 0.396 & 1.0 & 0.397 & 1.0 & 0.397 \\
\hline $\mathrm{CeO}_{2}$ & 0 & 0 & 0.25 & 0.10 & 0.5 & 0.201 & 0.75 & 0.303 & 1.0 & 0.404 \\
\hline Sum $\%$ & \multicolumn{2}{|c|}{100} & \multicolumn{2}{|c|}{100} & \multicolumn{2}{|c|}{100} & \multicolumn{2}{|c|}{100} & \multicolumn{2}{|c|}{100} \\
\hline
\end{tabular}

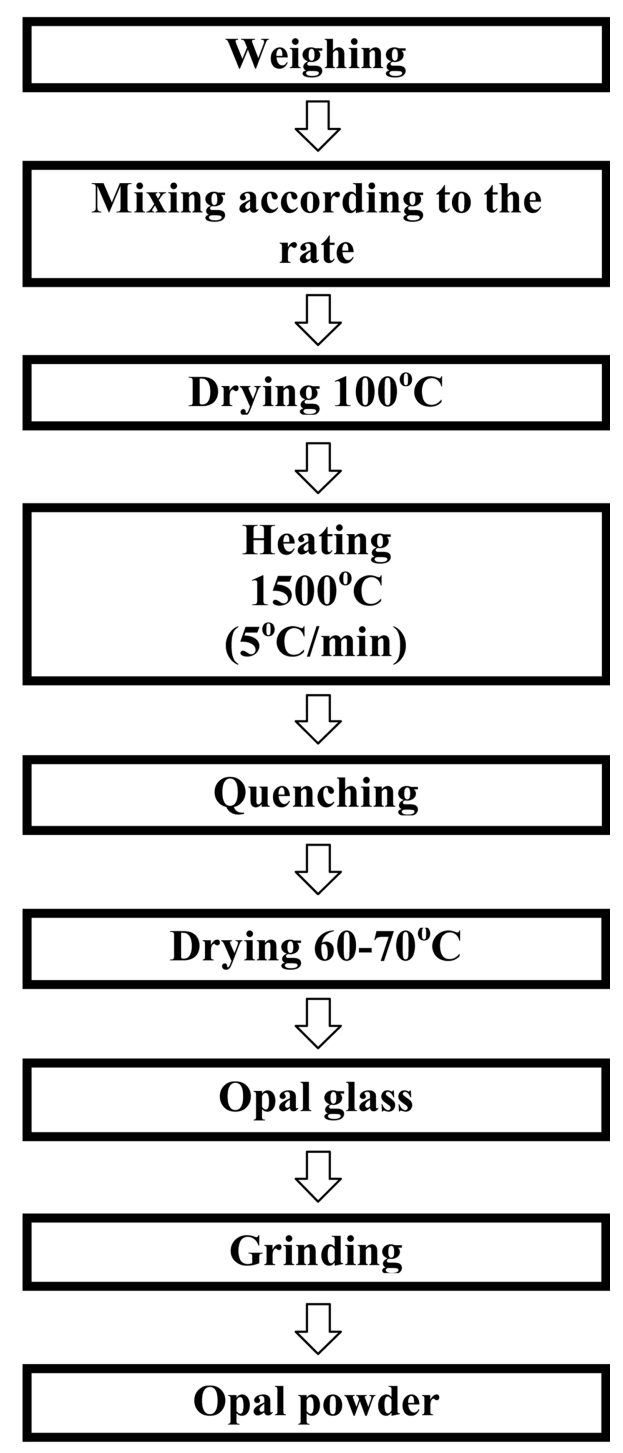

Fig. 1. Schematic representation of processing steps for the synthesis of opal glass.

samples were dried in the drying oven at $60{ }^{\circ} \mathrm{C}$ and then taken out of the crucible. The opal powders was made from the quenched glass by using pestle and mortar.

The opal powders thus made were characterized. The crystal structure by measurement of X-ray diffraction (XRD, $\mathrm{CuK} \alpha_{1}$ radiation $(\lambda=0.15406 \mathrm{~nm}$ ), D1w, Shimadzu, Japan) over the $2 \theta$ range of $20^{\circ}$ to $80^{\circ}$ at a scan rate of $2 \%$ min. Besides, particle size and morphology were observed by transmission microscopy TEM(Sirion, FEI, Netherland). The optical properties and transparency of opal glass was measured by using the Ultraviolet visible spectroscopy and Color spectrometer.

\section{Results and Discussion}

The chemical composition of opal glass as shown in Table 1, Table 2 and Table 3 were prepared to form group 1,2 and 3 respectively. Fig. 1 shows schematic representation of processing steps for the synthesis of opal glass and the photo images of opal glass samples after quenching are shown in Fig. 2. Effect of $\mathrm{TiO}_{2}, \mathrm{BaF}_{2}, \mathrm{CeO}_{2}$ on color of opal glass was observed through the optical images of the samples. The color of opal glass changes with corresponding change in the content of $\mathrm{TiO}_{2}, \mathrm{BaF}_{2}$ and $\mathrm{CeO}_{2}$. This was confirmed by the observations carried out by the naked eyes. In particular, the samples which contain the highest $\mathrm{TiO}_{2}, \mathrm{BaF}_{2}$ and $\mathrm{CeO}_{2}$ content have shown color changes more apparently than other samples that include lower additive content. In addition, the changes of color are more prominently observed and analyzed by ultraviolet visible spectroscopy, color spectrometer and transmission microscopy(TEM).

\subsection{XRD measurement}

X-ray diffraction pattern was studied to investigate the effect of additive on opal glass and to determine the crystal structure. XRD patterns collected from opal samples in group 1, group 2 and group 3 is shown in Fig. 3, 4 and 5 , respectively. In XRD results, opal powders basically appears to be in non-crystalline form. This clearly shows 


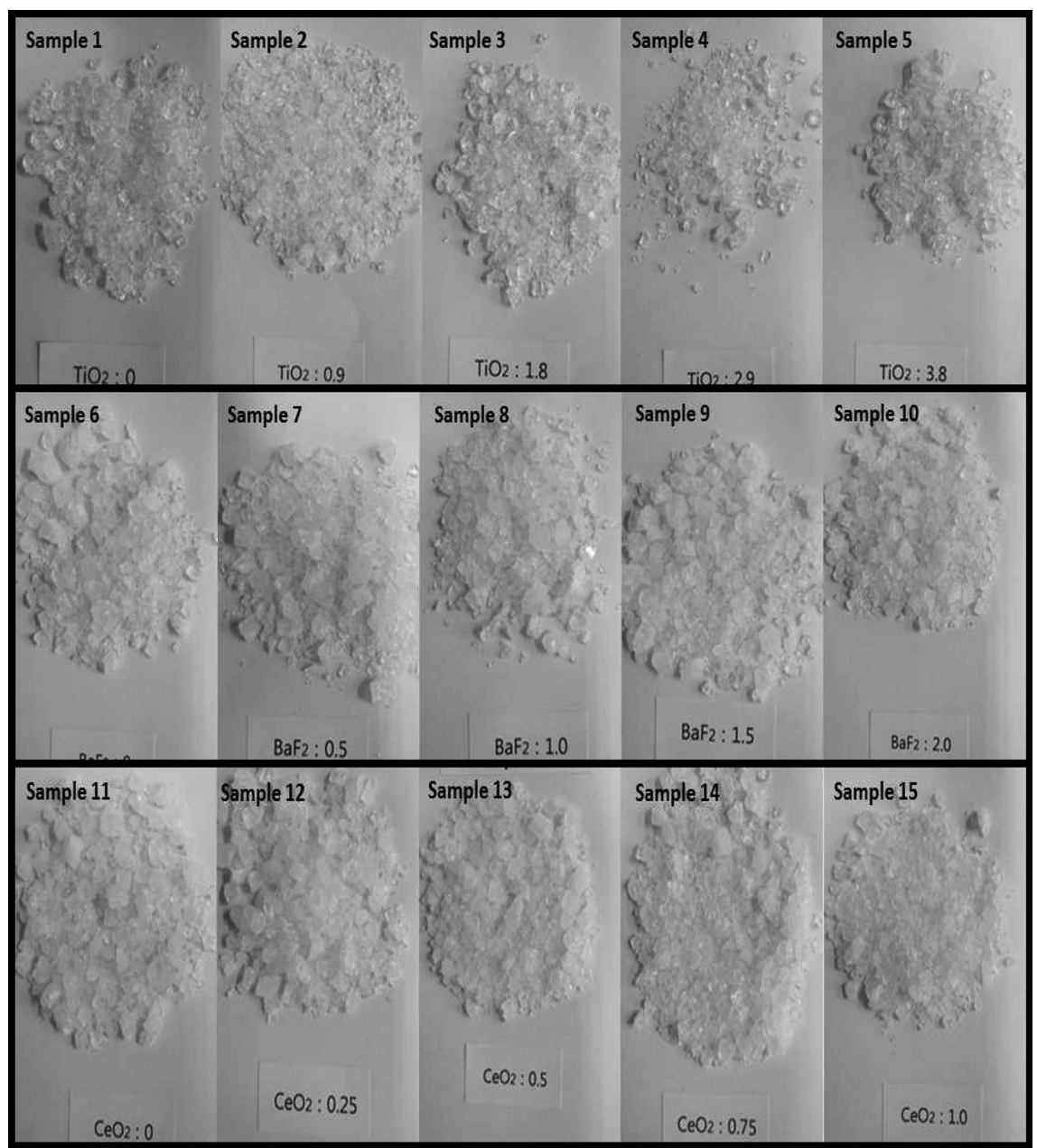

Fig. 2. The images of opal glass sample after quenching.

that opal powders are amorphous regardless of the kind of additives and its content.

In the vicinity of $2 \theta \approx 12-13^{\circ}$ in Fig. 3 , the XRD

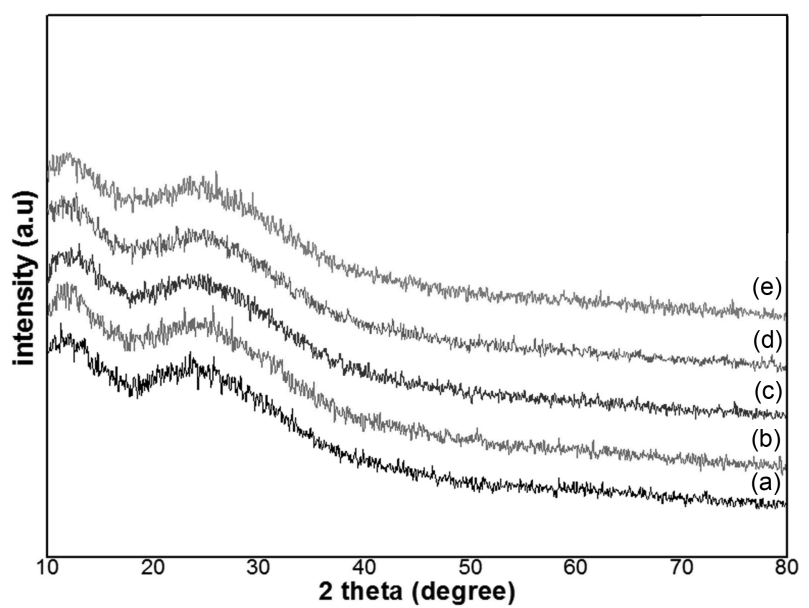

Fig. 3. XRD patterns of opal powder samples obtained at various $\mathrm{TiO}_{2}$ content (group 1); (a) $0 \%$ mole, (b) $0.29 \%$ mole, (c) $0.6251 \%$ mole, (d) $0.959 \%$ mole and (e) $1.297 \%$ mole $\mathrm{TiO}_{2}$. pattern of opal samples belonging to group 1 shows wide width and asymmetric peak. Amorphous structure was observed in all the groups, however, different peaks were

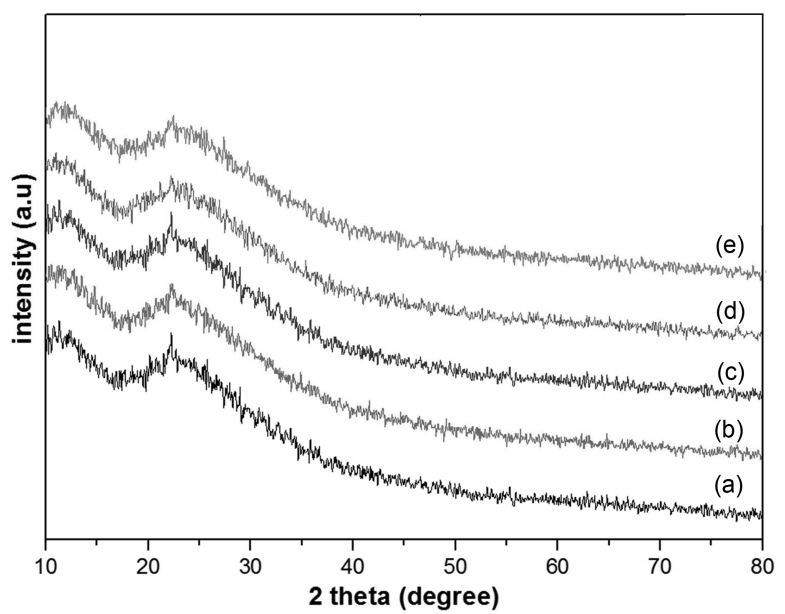

Fig. 4. XRD patterns of opal powder samples obtained at various $\mathrm{BaF}_{2}$ content (group 2); (a) $0 \%$ mole, (b) $0.197 \%$ mole, (c) $0.396 \%$ mole, (d) $0.596 \%$ mole and (e) $0.797 \%$ mole $\mathrm{BaF}_{2}$. 


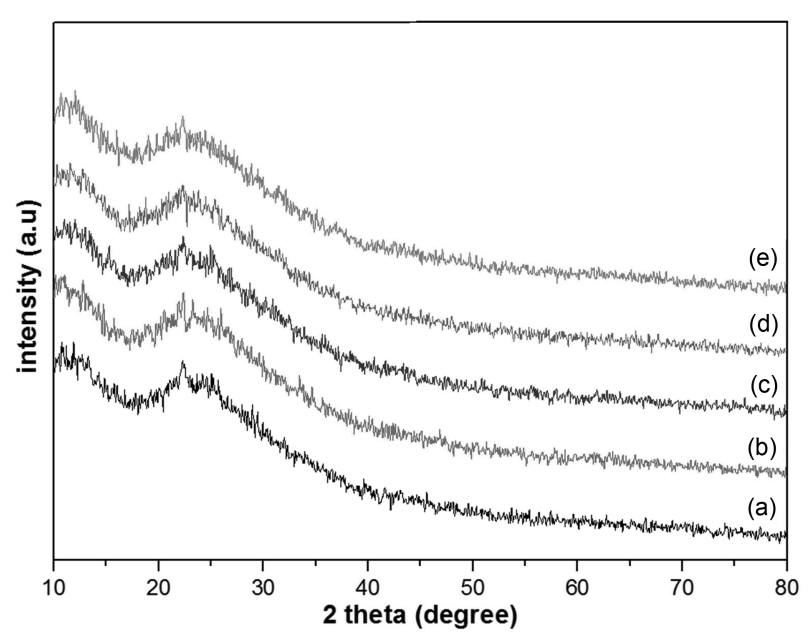

Fig. 5. XRD patterns of opal powder samples obtained at various $\mathrm{CeO}_{2}$ content (group 3); (a) $0 \%$ mole, (b) $0.1005 \%$ mole, (c) $0.201 \%$ mole, (d) $0.303 \%$ mole and (e) $0.4042 \%$ mole $\mathrm{CeO}_{2}$.

observed by varying contents of $\mathrm{TiO}_{2}, \mathrm{BaF}_{2}$ and $\mathrm{CeO}_{2}$.

\subsection{UV transmittance measurement}

The samples were optically characterized. Transmittance measurements are the best way to evaluate the quality of photonic crystals. Transmittance is the fraction of incident light(or other electromagnetic radiation) at a specified wavelength that passes through a sample. UV transmittance spectra for opal powder(15 samples) are shown in Fig. 6, Fig. 7 and Fig. 8.

UV transmittance spectra was recorded in Fig. 6 at different chemical composition of 5 samples in group 1 which was intended to investigate the effect of Titanium oxide $\left(\mathrm{TiO}_{2}\right)$. The effect of $\mathrm{TiO}_{2}$ on opal microstructure was clearly compared in sample 5 and sample 1 , with 1.297 mole $\%$ of $\mathrm{TiO}_{2}$ composition and without $\mathrm{TiO}_{2}$, respec-

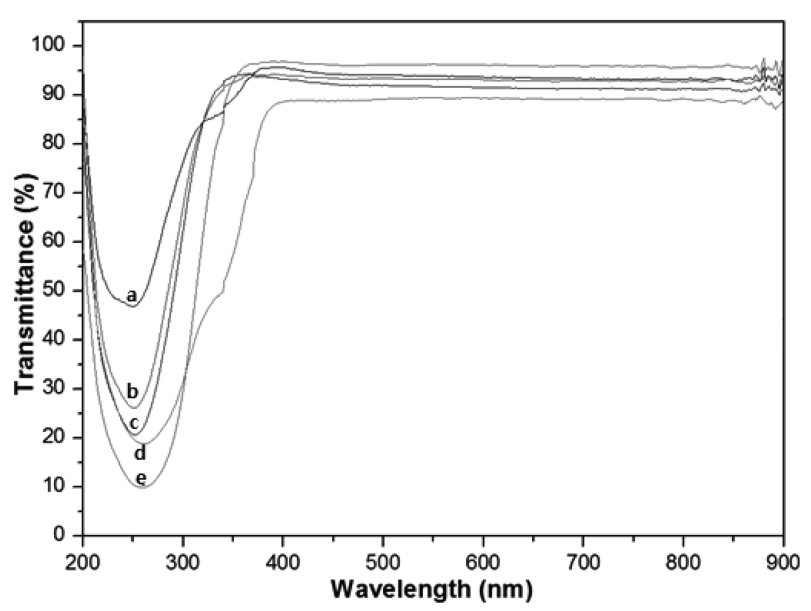

Fig. 6. UV transmittance spectra of 5 opal samples obtained at various $\mathrm{TiO}_{2}$ content (group 1) ; (a) $0 \%$ mole, (b) $0.29 \%$ mole, (c) $0.6251 \%$ mole, (d) $0.959 \%$ mole and (e) $1.297 \%$ mole $\mathrm{TiO}_{2}$. tively in Fig. 6. It is clearly seen that the sample 5 which contain $1.297 \mathrm{~mole} \%$ of $\mathrm{TiO}_{2}$ shows the transmittance maximum $(96 \%)$ in range of visible light wavelength (400$700 \mathrm{~nm}$ ). However, in the wavelength range of $200 \mathrm{~nm}$ to $400 \mathrm{~nm}$, transmittance of samples in group 1 tend to show the convex spectrums from $95 \%$ to $10 \%$.

Functional opals prepared by $\mathrm{TiO}_{2}$ additive where the play of color reflected strongly in the far ultraviolet and blue region of 200 400 $\mathrm{nm}$ but reflections of the red and green region were very poor. In blue spectrum region, as the content of $\mathrm{TiO}_{2}$ increases, the reflectance value was observed to be higher in the wavelength region. This result and the Opal images in Fig. 2 proved the role of $\mathrm{TiO}_{2}$ additive on opalescence property of the glass. Opalescence phenomenon usually occurs in the blue spectrum and is caused by the reflection of short wavelength light. However, the structural pattern of Opal is the reason of

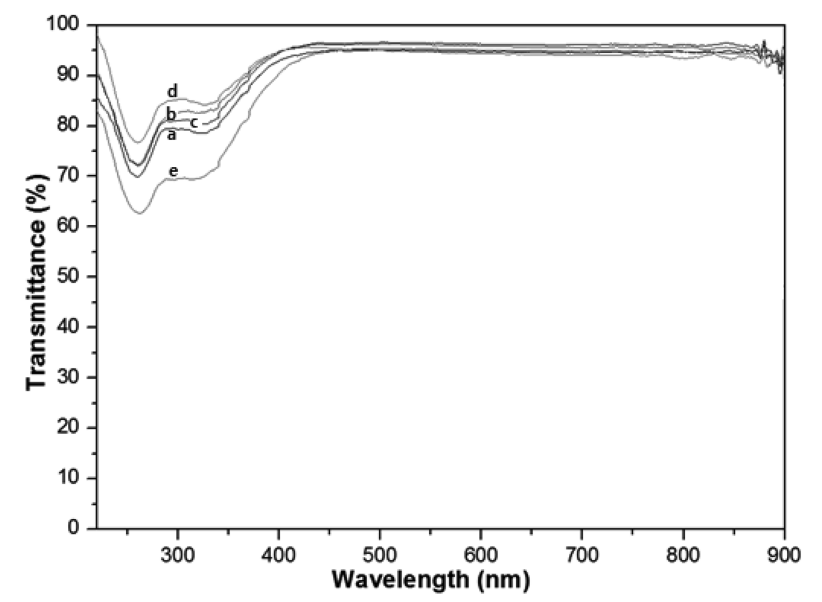

Fig. 7. UV transmittance spectra of 5 opal samples obtained at various $\mathrm{BaF}_{2}$ content (group 2); (a) $0 \%$ mole, (b) $0.197 \%$ mole, (c) $0.396 \%$ mole, (d) $0.596 \%$ mole and (e) $0.797 \%$ mole $\mathrm{BaF}_{2}$.

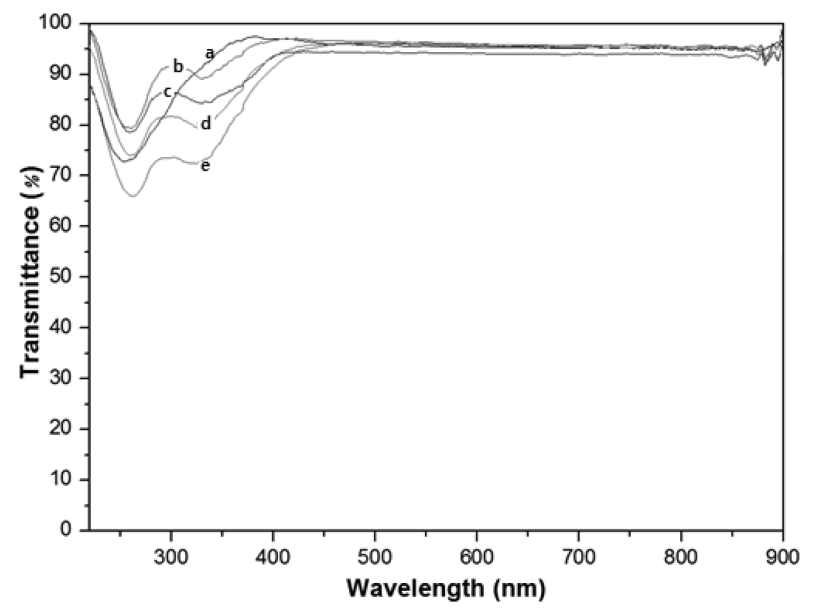

Fig. 8. UV transmittance spectra of 5 opal samples obtained at various $\mathrm{CeO}_{2}$ content (group 3); (a) $0 \%$ mole, (b) $0.1005 \%$ mole, (c) $0.201 \%$ mole, (d) $0.303 \%$ mole and (e) $0.4042 \%$ mole $\mathrm{CeO}_{2}$. 
opalescence phenomenon thus the reflection of short wavelength.

One more apparent thing is the difference between the spectrum in group 1 and other group. There is a constant and high transmittance at around $300 \mathrm{~nm}$ in group 2 and group 3, the end of the UV range and the beginning of visible range, which confirms observations carried out by the naked eyes. Fig. 7 shows UV transmittance spectra recorded at different chemical composition of five samples in group 2. A bimodal shape reflectance was observed in the region of $200 \sim 450 \mathrm{~nm}$. The peaks with highest reflectance were observed in wavelength of 260 and $350 \mathrm{~nm}$ regardless of contents of the additive. The synthesized opal in Fig. 7 showed the transmittance of 70 to $95 \%$ in region of $200 \sim 450 \mathrm{~nm}$. However, the reflectance of approximately $40 \%$ and $35 \%$ in range of $260 \mathrm{~nm}$ and 350 $\mathrm{nm}$ were shown in sample 10 which contained the highest $\mathrm{BaF}_{2}$ mole percent $(0.797 \%)$.

UV transmittance spectra of the samples in group 3 are exhibited in Fig. 8. The noticeable difference between transmittance spectra of Opal sample in 3 groups is the number of peaks was shown in the diagram. Due to the number of peaks were shown as the influence of chemical composition on light propagation in the photonic crystal. In the wavelength range of $200 \sim 450 \mathrm{~nm}$, the transmittance spectra of group 1(effect of $\mathrm{TiO}_{2}$ ) have only one peak, while those of group 2(effect of $\mathrm{BaF}_{2}$ ) and group 3(effect of $\mathrm{CeO}_{2}$ ) have 2 shift peaks except the sample 11. This fact is thought to be due to the effect of $\mathrm{CeO}_{2}$ content. The samples in both group 2 and group 3 that comprise $\mathrm{CeO}_{2}$ have two spectral peaks and the sample 11 which contains $\mathrm{CeO}_{2}$ has only one peak spectra. Further observations indicate that, with the increasing content of $\mathrm{CeO}_{2}$, the reflectance of Opal sample increased and reflected range became wider.

As a consequence, a number of peaks were illustrated as the effect of $\mathrm{CeO}_{2}$ composition on the light propagation in the photonic crystal. Moreover, the reduction of transmittance led to opalescence feature.

\subsection{Color spectrometer measurement}

Other method to characterize the morphologies of the Opal samples is the use of color spectrometer. The phenomenon of opalescence or the change of color can be determined quantitatively with the color spectrophotometer. For this purpose, the $L, a, b$ values were measured in transmission and in reflection on a black base in the photometer. In the $L, a, b$ color system, a positive $b$ value represents the yellow part of the light; on the other hand, a negative $b$ value represents its blue part. The higher the absolute amount, the more intense the color. The color spectral diagram and standard scale units were investigated to observe the change of the color of the samples or to determine the exact color of Opal glass. Graphical representation of the L, a, b color sphere system is shown in Fig. 9.

In the present work, the experiment measured $\mathrm{L}, \mathrm{a}, \mathrm{b}$ values for samples as shown in Table 4 . The increase of mole ratio of $\mathrm{TiO}_{2}$ corresponded to fluctuation of $a$ value and $b$ value while $L$ value changed slightly. Transmittance of sample $5\left(1.297 \mathrm{~mole} \%\right.$ of $\mathrm{TiO}_{2}$ content $)$ was shown as $10 \%$ (Fig. 5) and minimum $a$ value(-0.077), maximum $b$ value $(-0.214)$. Color change of the Opal sample 5 was most clearly expressed in group 1 . In addition, the decrease of the transmittance corresponded to the increase of opalescence. Based on the Table 4 and Fig. 7, $L$ values of the samples in group 2 were similar. However, transmittance of sample $10\left(0.797 \mathrm{~mole} \%\right.$ of $\mathrm{BaF}_{2}$ content $)$ was $63 \%$ $68 \%$, negative $a$ value $(-0.104)$, positive $b$ value $(0.21)$. It implies color change was most apparent in opal sample 10 of group 2. In another case, transmittance of sample $15\left(0.404 \mathrm{~mole} \%\right.$ of $\mathrm{CeO}_{2}$ content) was $65 \%$ and $71 \%$, negative $a$ value $(-0.117)$ and maximum $b$ value $(-0.062)$. As a result, color change of the opal sample 15 was most apparent in group 3. These results indicate the important role of chemical additives $\left(\mathrm{TiO}_{2}, \mathrm{BaF}_{2}\right.$ and $\left.\mathrm{CeO}_{2}\right)$ in the
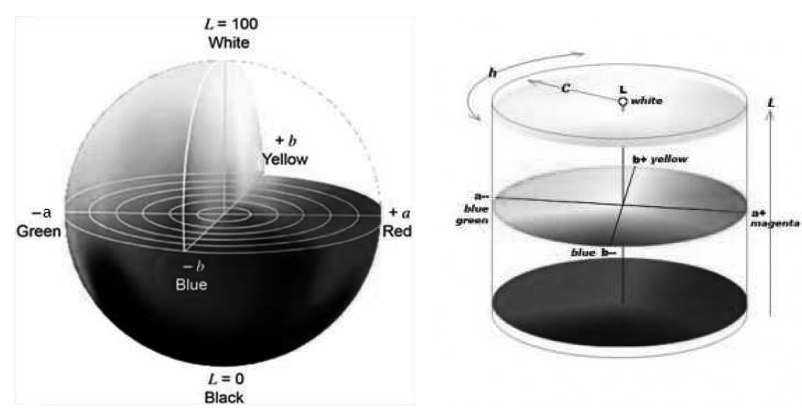

Fig. 9. Graphical representation of the Lab color sphere.

Table 4. $\mathrm{L}$, a, $\mathrm{b}$ values of opal samples obtained at various $\mathrm{TiO}_{2}, \mathrm{BaF}_{2}, \mathrm{CeO}_{2}$ content.

\begin{tabular}{ccc}
\hline Group 1: Effect of $\mathrm{TiO}_{2}$ & Group 2: Effect of $\mathrm{BaF}_{2}$ & Group 3: Effect of CeO \\
\hline Sample 1: $\mathrm{L}=98.298 \mathrm{a}=-0.013 \mathrm{~b}=-0.383$ & Sample 6: $\mathrm{L}=98.314 \mathrm{a}=-0.022 \mathrm{~b}=-0.385$ & Sample 11: $\mathrm{L}=98.226 \mathrm{a}=0 \mathrm{~b}=-0.314$ \\
Sample 2: $\mathrm{L}=98.239 \mathrm{a}=0.034 \mathrm{~b}=-0.482$ & Sample 7: $\mathrm{L}=98.298 \mathrm{a}=-0.049 \mathrm{~b}=-0.289$ & Sample 12: $\mathrm{L}=98.276 \mathrm{a}=-0.057 \mathrm{~b}=-0.239$ \\
Sample 3: $\mathrm{L}=98.238 \mathrm{a}=0.034 \mathrm{~b}=-0.482$ & Sample 8: $\mathrm{L}=98.317 \mathrm{a}=-0.003 \mathrm{~b}=-0.384$ & Sample 13: $\mathrm{L}=98.280 \mathrm{a}=0.001 \mathrm{~b}=-0.348$ \\
Sample 4: $\mathrm{L}=98.247 \mathrm{a}=-0.009 \mathrm{~b}=-0.316$ & Sample 9: $\mathrm{L}=98.296 \mathrm{a}=-0.001 \mathrm{~b}=-0.409$ & Sample 14: $\mathrm{L}=98.288 \mathrm{a}=0.013 \mathrm{~b}=-0.377$ \\
Sample 5: $\mathrm{L}=98.247 \mathrm{a}=-0.077 \mathrm{~b}=-0.214$ & Sample 10: $\mathrm{L}=98.043 \mathrm{a}=-0.104 \mathrm{~b}=0.210$ & Sample 15: $\mathrm{L}=98.211 \mathrm{a}=-0.117 \mathrm{~b}=-0.062$ \\
\hline
\end{tabular}


play of color of the glass.

\subsection{Schematic illustration of the opal structure}

The sample $5\left(3.882 \% \mathrm{TiO}_{2}\right)$ and sample $15\left(1 \% \mathrm{CeO}_{2}\right)$ were characterized by TEM and HRTEM in order to investigate effect of $\mathrm{TiO}_{2}$ and $\mathrm{CeO}_{2}$ on crystallization.
$\mathrm{BaF}_{2}$ was not crystallized after quenching at $1500^{\circ} \mathrm{C}$ because the melting point of $\mathrm{BaF}_{2}$ is $1368^{\circ} \mathrm{C}$. The TEM images of sample 5 and sample 15 are shown in Fig. 10. $\mathrm{TiO}_{2}$ crystal used as functional additive was observed within amorphous opal glass as shown in Fig. 10A. The size of $\mathrm{TiO}_{2}$ crystal was $10 \sim 20 \mathrm{~nm}$.
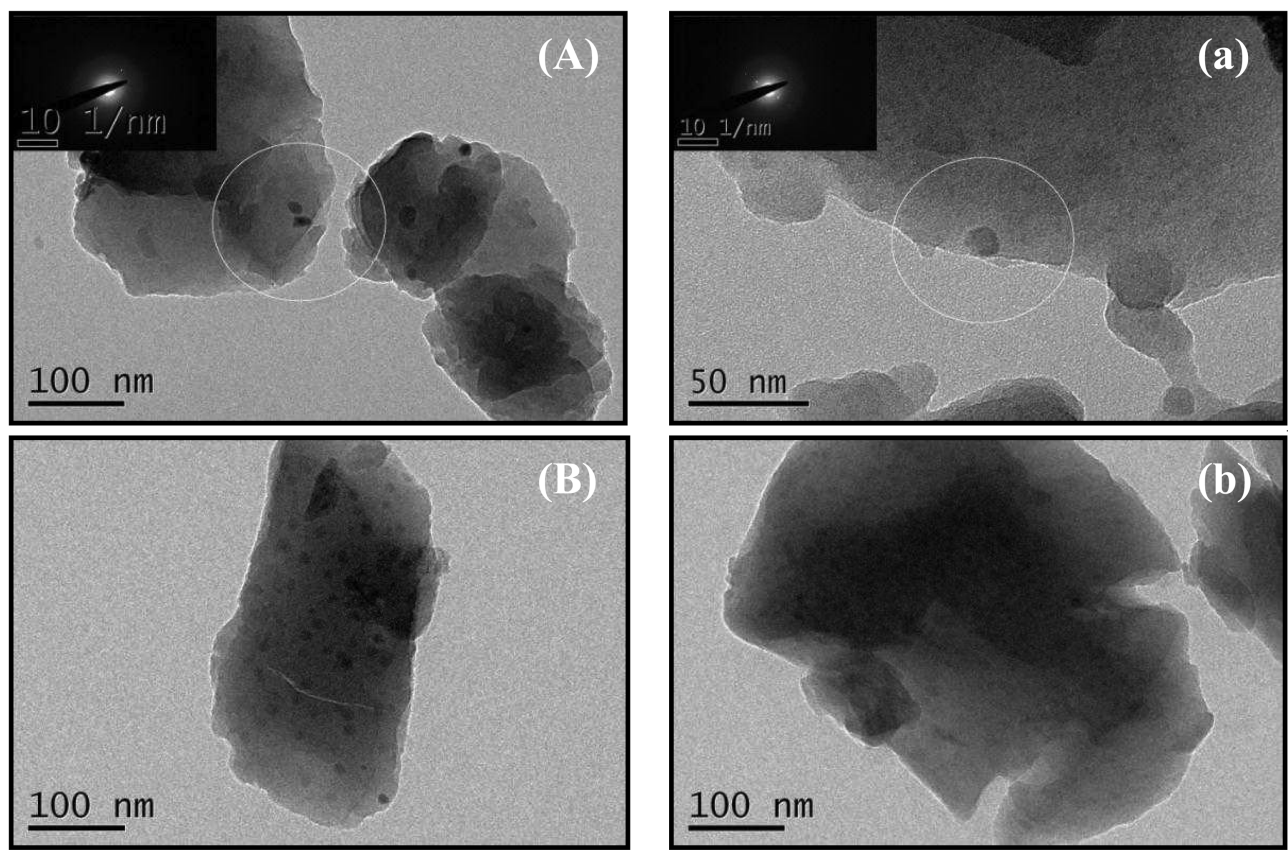

Fig. 10. TEM images of the opal powders Opal sample 5 (A, a) and opal sample 15 (B, b).
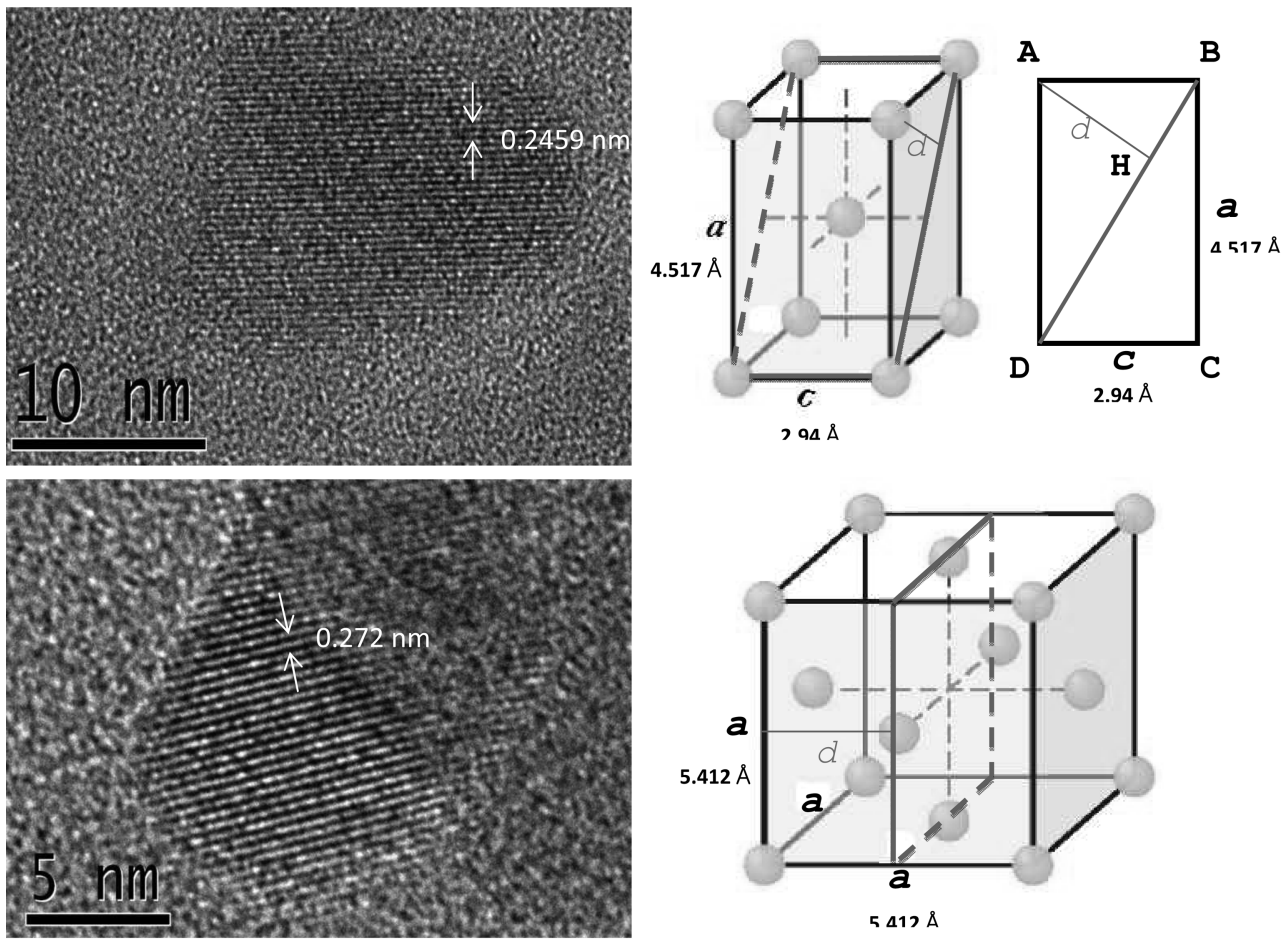

Fig. 11. HRTEM images of the opal structure and schematic illustration of the opal structure; (a) Tetragonal structure ( $\left.\mathrm{TiO}_{2}-\mathrm{rutile}\right)$ and illustration Tetragonal structure $\left(\mathrm{TiO}_{2}\right.$ - rutile) and (b) Face centered cubic structure $\left(\mathrm{CeO}_{2}\right)$ and illustration Face centered cubic structure $(\mathrm{CeO})$. 
The schematic illustration of crystal structures and HRTEM image of $\mathrm{TiO}_{2}$ within opal powder(sample 5) are shown in Fig. 11a, it can be seen that there are many ordered crystals. These crystals are thought to be of $\mathrm{TiO}_{2}$ $(0.2459 \mathrm{~nm})$. According to schematic illustration, the distance between planes of crystal lattice $d$ value(AH side) calculated using the lattice constant of the tetragonal structure of rutile from plane of (101). As schematic illustration shows, $d$ value is equal to length of $\mathrm{AH}$ of triangle $\mathrm{ABD}$. The length of $\mathrm{AH}$ was calculated according to congruent triangles(HBA and $\mathrm{ABD})$ :

$$
\begin{aligned}
\frac{\mathrm{AH}}{\mathrm{DA}}=\frac{\mathrm{AB}}{\mathrm{BD}} \rightarrow d=\mathrm{AH}= & \frac{\mathrm{DA} \cdot \mathrm{AB}}{\mathrm{BD}}=\frac{a c}{\sqrt{c^{2}+a^{2}}} \\
& =2.4640(\AA)=0.2460 \mathrm{~nm} .
\end{aligned}
$$

The calculated $d$ value is very similar to that estimated by analysis of the HRTEM image $(d=0.2459 \mathrm{~nm})$. It means Opal glasses belonging to group 1 have tetragonal lattice structure of $\mathrm{TiO}_{2}$ (rutile).

Basically, the content of the samples in all the three groups are similar and their remarkable difference is $\mathrm{TiO}_{2}, \mathrm{CeO}_{2}$ and $\mathrm{BaF}_{2}$ content. Therefore, ordered forms of inter-plane distance in crystal structure arrange differently. A schematic illustration representing the cubic structure of $\mathrm{CeO}_{2}$ and HRTEM image of Opal powder in group 3 are shown in Fig. 11b. The spacing between planes of crystal lattice $d$ value $(d=5.412 / 2=2.706 \AA=$ $0.2706 \mathrm{~nm}$ ) calculated using the lattice constant of the face centered cubic structure(FCC) from direction of [010] and plane of (200) is very similar to that estimated by analysis of the TEM image $(d=0.272 \mathrm{~nm})$. As a result, opal glasses of group 3 have lattice structure of cubic structure.

\section{Conclusion}

Opal glass having different chemical compositions were synthesized and transparent of glass were obtained after melting. Effect of $\mathrm{TiO}_{2}, \mathrm{BaF}_{2}$ and $\mathrm{CeO}_{2}$ content on color of opal glass was studied by observing images of the Opal samples.

Effect of $\mathrm{TiO}_{2}, \mathrm{BaF}_{2}$ and $\mathrm{CeO}_{2}$ on color of opal samples was also studied by comparing L, a, b scale index. The samples which contain the highest $\mathrm{TiO}_{2}, \mathrm{BaF}_{2}$ and $\mathrm{CeO}_{2}$ ( $\mathrm{L}$ value $\min$, a min, b max) have the most noticeable color. With the increasing mole of $\mathrm{TiO}_{2}$, a decrease in the value of $a$ and rise in the value of $b$ was observed while $\mathrm{L}$ value changed slightly. However, effect of $\mathrm{CeO}_{2}$ is most clear because of the appearance of second spectral peaks.

Opalescence of opal samples in group 2 and group 3 are stronger than that in group 1 because of the shift peaks. In the wavelength range of $200-450 \mathrm{~nm}$, the transmittance spectra of group 1 (effect of $\mathrm{TiO}_{2}$ ) have only one peak, while those of group 2(effect of $\left.\mathrm{BaF}_{2}\right)$ and group 3 (effect of $\mathrm{CeO}_{2}$ ) have 2 shift peaks except the sample 11. This is because of the $\mathrm{CeO}_{2}$ content. The samples in both group 2 and group 3 that comprise $\mathrm{CeO}_{2}$ are having two peaks spectra and the sample 3 which does not include $\mathrm{CeO}_{2}$ have only one peak spectra. A number of peaks were illustrated as the effect of chemical composition on light propagation in the photonic crystal. This expresses the optical property of Opal glass.

The ordered forms of inter-plane distance in crystal structure arrange differently $(d$-spacing between planes sized nanometer: $0.246 \sim 0.2706 \mathrm{~nm}$ ). The distance between planes of crystal lattice $d$ value calculated using the lattice constant of the tetragonal structure (rutile, $\mathrm{TiO}_{2}$ ) is very similar to that estimated by analysis of the HRTEM image. It implies Opal glasses which belong to group 1 having lattice structure as tetragonal structure and group 3 having lattice structure as cubic structure $\left(\mathrm{FCC}, \mathrm{CeO}_{2}\right)$.

\section{References}

1. A. Imhof and D. J. Pine, Nature, 389, 948 (1997).

2. F. Meseguer, A. Blanco, H. Míguez, F. García-Santamaría, M. Ibisate and C. López, Colloids Surf. A, 202, 281 (2002).

3. Y. Ma, J. -F. Chen, Y. Ren and X. Tao, Colloids Surf. A, 370, 129 (2010).

4. Y. Jin, Y. Zhu, X. Yang, C. Wei and C. Li, Mater. Chem. Phys., 106, 209 (2007).

5. A. V. Baryshev, A. A. Kaplyanskii, V. A. Kosobukin, M. F. Limonov, K. B. Samusev and D. E. Usvyat, Phys. Solid State, 45, 459 (2003).

6. Y. Li, F. Piret, T. Léonard and B. -L. Su, J. Colloid Interface Sci., 348(1), 43 (2010).

7. A. Rèza, I. Šimkiene, R. Vaišnoras, C. Lopez, D. Golmayo and J. Babonas, Photonics and Nanostructures, 9, 82 (2011).

8. A. M. Kapitonov, Photonics and Nanostructures, 6, 194 (2008).

9. C. L. Huisman, J. Schoonman and A. Goossens, Sol. Energy Mater. Sol. Cells, 85, 115 (2005).

10. L. Pallavidino, D. Santamaria Razo, F. Geobaldo, A. Balestreri, D. Bajoni, M. Galli, L. C. Andreani, C. Ricciardi, E. Celasco, M. Quaglio and F. Giorgis, J. NonCryst. Solids, 352, 1425 (2006).

11. M. Arbab, V. K. Marghussian, H. Sarpoolaky and M. Kord, Ceram. Int., 33, 943 (2007).

12. M. Abdel-Baki and F. El-Diasty, Curr. Opin. Solid State Mater. Sci., 10, 217 (2006).

13. N. P. Johnson, D. W. McComb, A. Richel, B. M. Treble and R. M. De La Rue, Synth. Met., 116, 469 (2001). 